\title{
Women Entrepreneurship and Poverty Alleviation in Awka Metropolis
}

\author{
Agbionu $\mathrm{EO}^{1 *}$, Agbionu $\mathrm{CU}^{2}$, Ikon $\mathrm{MA}^{2}$ and Chinwe $\mathrm{OV}^{2}$ \\ ${ }^{1}$ Department of Adult Education, Nnamdi Azikiwe University, Awka, Nigeria \\ ${ }^{2}$ Department of Business Administration, Nnamdi Azikiwe University, Awka, Nigeria
}

\begin{abstract}
Despite the provision of soft loans by the last presidential government in Nigeria through the Central Bank, women entrepreneurs in Awka metropolis still complain of lack of financial assistance from government and poor moral support from members of their families as impediments against their contributions in poverty alleviation. In view of the above, the study examined the relationship between government financial assistance and family moral support on the performance and commitment of women entrepreneurs in Awka metropolis. Research questions and hypotheses were formulated based on the research problems and objectives. Survey design was used to collect the data by the use of a structured questionnaire. The instrument was subjected to validity and reliability tests and found adequate for the study. The data collected were analyzed using frequency distributions and percentages. Pearson's Product Moment Correlation was used to test the hypotheses while Probable Error of Correlation was used to test for the significance of correlation. The result of the significance shows that the results of the Probable Errors in the two hypotheses were both lower than the coefficients of correlations. This made the two null hypotheses to be rejected while the alternatives were accepted. Major finding, conclusion and recommendations are that since the financial support from government and moral support from family members were found to be very significant in the performance and commitment of women entrepreneurs in Awka metropolis for poverty alleviation purposes, they should be highly encouraged.
\end{abstract}

Keywords: Women; Entrepreneurship; Poverty; Alleviation

\section{Introduction}

\section{Background of the study}

Entrepreneurship has been globally acclaimed as the bedrock of any economy. It has been seen by many people literate and illiterate alike as the wheel through which the growth and development of economies all over the world revolves. Many countries of the world have practically applied entrepreneurship in their economic growth and development and have observed that it led to the survival, success and sustainability of their economy [1]. The practical evidence in those countries especially the CRIBA countries which are China, Russia, Indonesia, Belgium and Argentina are clear evidences of the roles of entrepreneurship in the growth and development of economies all over the world [2].

Entrepreneurship has been variously defined by experts from their professional afflictions. The psychologist on his own sees an entrepreneur as one who is moved by a strong desire to achieve his objectives. He has a need, motivated by that need he works hard to achieve the need. He is moved by his values and positive attitudes that propel him to work hard to achieve his goals. An ordinary Business man or manager of an organization sees an entrepreneur as a big threat to his products and services. The entrepreneur here is seen as an aggressive competitor who must be stopped at all costs. The investors in business enterprises see an entrepreneur as "an ally, someone good to invest in", while the capitalist philosopher sees him as a person who creates wealth and generates employment for others, he reduces waste in production process and can make the society to be happy [3].

This shows that entrepreneurship is multi-disciplinary. The above notwithstanding, Richard Cantillion- a renowned economist during the 1700 s used the word entrepreneur to refer to someone who takes active risk bearing role in pursuing opportunities. Perhaps the explanation of the word entrepreneurship provided by Coulter provides a clear understanding of what entrepreneurship is all about. She stated that entrepreneurship has been defined by many authors with such words as new, innovative, flexible, dynamic, and creative and risk taking.
From the above definitions, it is clear that no matter the profession an entrepreneur is coming from, he must be able to identify untapped opportunities, creates something new, and must be innovative, flexible, dynamic and above all ready to take calculated risks.

During the last two decades, literature in academics has witnessed a surge of interest on female entrepreneurship in the global arena. According to Carter and Cannon, women entrepreneurship is seen to attract considerable amount of attention as a subject of academic debate in its own right [4]. Verhcuil posits that such interests are due mainly on the fact that female entrepreneurs are now considered important forces in economic growth and development of their nations which is the crux of poverty alleviation. Women entrepreneurs are women who take part in entrepreneurial activities either in full time, or part time small scale or large scale or even in a multinational environment. In support of the above, Chinonye affirmed that women entrepreneurs are simply women that participate in total entrepreneurial activities, who take risks involved in combining resources together in a unique way so as to take advantage of the opportunities identified in their immediate environments through the production of goods and services [5]. This no doubt hinges on the fact that women have been and are still agents of poverty alleviation because any meaningful growth and development must address the tenets of poverty alleviation.

Poverty alleviation on its own is a process aimed at reducing the incidence of poverty in any environment. He continued that most developed and developing countries of the world have at one time or

*Corresponding author: Agbionu EO, Department of Adult Education, Nnamdi Azikiwe University, Awka, Nigeria; E-mail: uctinagbionu@gmail.com

Recieved September 08, 2015; Accepted October 27, 2015; Published November 10, 2015

Citation: Agbionu EO, Agbionu CU, Ikon MA, Chinwe OV (2015) Women Entrepreneurship and Poverty Alleviation in Awka Metropolis. J Entrepren Organiz Manag 4: 158. doi:10.4172/2169-026X.1000158

Copyright: (c) 2015 Agbionu EO, et al. This is an open-access article distributed under the terms of the Creative Commons Attribution License, which permits unrestricted use, distribution, and reproduction in any medium, provided the original author and source are credited. 
another felt the impact of poverty. To be poor means a condition of lack of fundamental freedom of action and choice that the better-off take for granted. Nwobi added that poverty is reflected in lack of adequate food, shelter, education and health, deprivation that keeps them from leaving the kind of life everyone values. According to World Bank report in 2001, people living in abject poverty face extreme vulnerability of illhealth of different types and degrees, economic dislocation and other forms of natural disaster. Studies by Mayonx and Ndubuisi indicate that most of the women who are involved in micro small and medium scale enterprises (MSMEs) contributed more than $97 \%$ of all enterprises (10\% of nations GDP and $94 \%$ of the total share of the employment $[6,7]$. These are practical ways women have involved themselves in poverty alleviation. This confirms what Todaro stated that no nation can claim of eradicating poverty if it cannot show practical indication of increase in GDP, GNP and employment

Many women in many countries of the world have been forced by one circumstance or another to engage in alternative avenues of generating an income with a greater number of women setting up businesses to balance work and family commitments [8]. This is seen in a study by Walker where he argued that "women in businesses are a growing force in the economy and in transition environments. He added that the contribution of these women extend from the economic scheme to include the wider process of social transformation. Supporting the above view, UNIDO Report on Africa also acknowledges this trend as women were reported to be in charge of majority of business and economic activities in Africa [9-11].

The above findings reached a consensus that women own and operate around one-third of all businesses in the formal sector, and represent the majority of businesses in the informal sector.

The contribution of women in the growth and development of economies around the world calls for attention from government at all levels, family members and other stake holders to assist women to realize these goals, but it has not been so in some parts of the world especially in the developing world where Nigeria belongs. Women in Nigeria especially in the Awka Metropolis complain that they have not been receiving enough assistance and support from government as well as family members. Their claim is that in Nigeria, women are considered as second hand citizens and therefore are left without much help and assistance especially in the areas of their enterprising ventures. The researcher has been bordered and burdened by this development and wants to practically investigate these claims to see how authentic they are.

\section{Statement of the problem}

The changing trends in the socio-economic environment have given rise to many unplanned changes in the life style of people in the global environment. Traditionally, women are created to play supportive roles in family life. This idea was initiated by God Himself when he created Adam and saw that he needed a helper according to the Word of God in Genesis 2:21. From then onwards women continued to play supportive roles to the men. They are usually engaged in cooking, home management and children upbringing. The men in those days were seen fending for the family in the areas of building houses, paying children's school fees, providing financial assistance for huge expenses in the family. In those times again, it was only the man that engage in paid employment while the women were home keepers. But due to changes in socio-economic and cultural environments, women no longer play only supportive roles alone. They have to assume bread- winner roles in some cases in order to make sure that the family is protected, in peace and love.

In spite of all these remarkable reports on women and entrepreneurship, the reality of this relationship in many societies and transition economies is that female entrepreneurs consistently struggle and remain dormant without remarkable output due mainly to poor support from government and other relevant stakeholders. Reasons for this neglect on women are mainly because of the traditional societal placement of the woman. Women in the traditional society were relegated to the background during the past years in Nigeria. They have been neglected in many policy activities and decisions by the men folk usually because they see women as weak species. The promotion of women activities then in Nigeria remained disappointing and their contribution overlooked as a result of the "systematic neglect as a whole". But the story has recently changed, in the recent times. Women in Nigeria have permeated all aspects of the economy ranging from politics, law, economy, technology, agriculture just to name a few. Their contributions in these sectors are clear and unambiguous. People like Omotola Ekeinde, Geneviv Nnaji, Patience Ozokwor are few cases in the entertainment industry, while people like Chimananda Adichie have success stories in Arts and Literature and other people too numerous to mention in other aspects of live are practical examples of women participation and success in entrepreneurship.

In view of these tremendous contributions lately, Government at the federal has in the recent times recognized the indispensable roles of women especially in entrepreneurship. This is why the last Federal Government through the Central Bank mapped out a huge sum of money to encourage the entrepreneurial activities of the women but this financial assistance seem not to have reached these women since inception for reasons which the study will unravel. Though awareness has been created in developed countries on the contribution of women and so they have received much support from their family members to engage in enterprising ventures but in Nigeria, the story has remained different. It is so bad in Nigeria that some men do not even allow their wives to engage in productive ventures even after graduation from academic institutions for fear of one thing or another.

Despite all the recognition given to women in the recent times in support of their entrepreneurial activities, many women still complain of neglect and abandonment by government in support of their entrepreneurial activities in the areas of financial support, poor support from their husbands and family members, support and encouragement from the community and other exigencies that hinder women from putting in their best to perform excellently in entrepreneurial activities. The researcher is seriously disturbed by this ugly situation especially in relation with women entrepreneurs in Awka Metropolis. As a result of this disturbing situation, the researcher examined the actual situation in Awka metropolis to either agree with the claims of some of these women or disprove their assertions. The whole essence is to remedy the situation if it exists.

\section{Objectives of the study}

The main objective of the study is to examine the contribution of women entrepreneurs in alleviating poverty in Awka Metropolis. Specifically, the study ascertained:

1. The extent of influence of government's financial support on the performance of female entrepreneurs in alleviating poverty in Awka Metropolis.

2. The extent of influence of family moral support on the 
commitment of female entrepreneurs in alleviating poverty in Awka Metropolis.

\section{Research questions}

The research questions that were raised by the study are as follows:

1. To what extent has government's financial support influenced the performance of female entrepreneurs in alleviating poverty in Awka Metropolis?

2. To what extent has family members' moral support influenced the commitment of female entrepreneurs in Awka Metropolis?

\section{Hypotheses of the study}

The study formulated two research hypotheses as follows:

1. Government financial support has not significantly influenced the performance of female entrepreneurs in Awka Metropolis

2. Family members' moral support has not significantly influenced the commitment of female entrepreneurs in Awka metropolis.

\section{Significance of the study}

A study of this nature is expected to be useful to government officials in charge of policy formulation especially as it relates to the involvement of women in entrepreneurial activities in Nigeria using Awka Metropolis as a reference point.

It is also expected to be very useful to women in particular to enable them be aware of developments taking place in entrepreneurship as it affects them. The men, and in deed the general public and other stakeholders would derive tangible enlightenment on the recent development of women involvement in entrepreneurship. Other people who are expected to be duly educated by the study are the student researchers at all levels, independent researchers and other interested parties. This study is expected to fill gaps created in knowledge which has been created due to scanty studies on women entrepreneurship in Awka Metropolis.

\section{Scope of the study}

The variables covered by the study are limited to registered female entrepreneurs in Awka Metropolis who are both in manufacturing and service industries. The main areas of women entrepreneurship addressed by the study are the obstacles that affect the extent at which they contribute to poverty alleviation in Awka Metropolis. The independent variables of obstacles covered by the study are: government financial assistance, and family members' moral support, while the dependent variables of the study are the performance of female entrepreneurs and their commitment in alleviating poverty in Awka metropolis.

\section{Limitations of the study}

The study was challenged by such issues as getting the female entrepreneurs to respond to the questionnaires. Some of the entrepreneurs were not very literate to fill in the responses on the questionnaire but the researcher assisted them by interpreting the questions for them and filing in the gaps for them.

\section{Operational definition of key variables of the study}

Women entrepreneurship was decomposed based on the problem of the study which is the poor financial support women entrepreneurs receive from government and moral support they receive from their family members.

Poverty alleviation was decomposed based on the contribution of women entrepreneurs in poverty alleviation. The contribution of women entrepreneurs was measured using personal performance and commitment of women entrepreneurs in alleviating poverty in Awka metropolis.

Women entrepreneurs are hereby defined as all women who take active part in pursuing entrepreneurial activities in the manufacturing and service industries.

\section{Review of Related Literature}

\section{Conceptual review of the study}

The concept of entrepreneurship is rapidly gaining ground both in the academic and professional environments in many countries of the world as a way out of poverty through sustainable growth and development of global economies. Entrepreneurship is a concept in business environment that assures the psychological and financial risks of creating new ventures. The new ventures are created out of totally new ideas invented to fill existing gaps or opportunities in an environment [12]. New ventures can also be created from innovations of existing businesses. The whole essence in the second instance is to make "common things uncommon for sustainable growth and development in order to alleviate poverty.

The supposedly two ways of creating new ventures as discussed above were necessitated from popular view in the literature that entrepreneurship has been recognized as the bedrock of the economic growth which contributes more than $60 \%$ of nation GDP and GNPs as reported by Chinonye [5]. One may wonder why this has been so since before, entrepreneurship products were being produced at different economic and social environments. What is the magic which entrepreneurship does? In answer to the above questions, Garth stated that, the entrepreneur provides a dynamic economic system within the old inefficient method by applying new and modern efficient method of producing goods and services. It is now referred to as the central force for economic and social change and as a result, it requires that everyone (men and women) be involved in its operations. This further means that it should not be an exclusive concern of men. In other words, women are totally involved even from cradle.

Women on their own part have been strong agents of growth and development in many economies long before the origin of entrepreneurship. Studies by UNIDO found that the productivity of women especially in many industries empowers them and propels them to contribute significantly to the growth and development both in small and medium scale activities [9]. The contributions of women in economic activities, the report continued, are not only as a means of economic survival but also have a positive social repercussion for the women themselves and their social environment. This justifies the involvement of women not just in entrepreneurial activities but also in many social endeavors in the society at large instead of just being conscripted to be home keepers and children bearers.

Women involvement in entrepreneurship for poverty alleviation through sustainable growth and development of economies has been remarkable and tremendous in the recent times. It has resulted to significant economic growth and development of many economies globally. For instance, during the $20^{\text {th }}$ century, women activities in entrepreneurship according to Egwu "have witnessed monumental 
changes and have transformed women to be income earners and assets to their societies" [13]. This dynamism in the recent times on the roles of women according to her has led to the recognition of the potentials in women and their contribution to the national and international economies all over the world. In support of the above assertion, Chinonye observed that traditional roles of women in families are constantly changing as a result of changes in the family configuration and setting which have allowed women to undertake more practical and functional roles within the society [5]. In view of these changes, "there has been an influx of women into the main stream labor market, leading to the re-organization, the resolution of women's movements and the civil rights movements which have propelled women into non-traditional roles, and the explosion in the number of women entrepreneurs particularly over the last two decades".

The above changing roles of women have led to immeasurable contributions of women in entrepreneurship. Ubong have all explored the contributions of women entrepreneur as (a) empowering women especially the moral women (b) enhancing national productivity, (c) generating employment (d) development of economic and financial independence and social capabilities among women, (e) improving standard of living and self-confidence, and enhancing awareness, sense of achievement, improvement in decision making status, increasing of social interaction and improvement in leadership quality. Contributions of women are clear indication of their roles in poverty alleviation [14].

Poverty alleviation is a serious business in under-developed and developing countries of the world. Nnamani noted that Nigeria is fully identified as sitting uncomfortably in the bowels of poverty and so earned $154^{\text {th }}$ of 172 countries in the World Marginal Index (WMI). In 2010, Eyuiche categorically asserted that poverty persists in Nigeria due to economic backwardness; occasioned by low labor efficiency, factor immobility, limited specialization, in occupation and in trade, economic ignorance, values and social structure that minimizes the incentives for sustainable economic change. Poverty affects almost every nation developed and developing alike. The difference is the type of poverty a nation faces. Some nations face absolute poverty while some others face relative poverty. Absolute poverty according to Agbionu is a state where majority of the citizens do not afford the basic necessities of life while relative poverty is a state where an aspect of the population are affected by poverty due to one reason or the other which ordinarily should not have been so [12]. Anambra State where Awka belongs can be seen to be facing relative poverty and women who have been naturally made to be more in number than men in many nations of the world where Awka belongs can be fashioned to contribute their own quota in alleviating poverty in Awka metropolis.

The contribution of women is highly needed in Nigeria now that many poverty alleviation programs introduced by successive governments failed to achieve their objectives. Agbionu stated that one of the major reasons for the failure was because many of the programs were usually politically motivated with selfish interests [15]. For instance Eyuiche stated that Obasanjo led PDP government announced a ten billion naira poverty alleviation program sometime in May 2000. The program was criticized according to the report for its political undertone. The critics confirmed that the money was used to attract voters to PDP. Specifically, the report stated that $\$ 3,500$ of the money was given to each of the relations of party members while the poor people were left out. Many other programs aimed at alleviating poverty in Nigeria have all failed as well because of insincerity of the policy makers and policy implementers. Some of the policies for poverty alleviation would have yielded fantastic results but selfishness, insincerity, and other social ills crippled them. This is why poverty in Nigeria has persisted and if drastic measures are not put in place to address it, it will definitely drag the name and reputation of Nigeria to the mud hence this study.

In addition to the view above, McConnel is of the opinion that women have enormous potential to bring prosperity in the world and therefore encouraging women entrepreneurship is very important.

\section{Empirical review}

In the area of women helping to alleviate poverty, a study on Rural Women Ventures in Africa by OECD in 1998 showed that women produce more than $80 \%$ of goods for sub-Sahara, Africa, $34 \%$ for North Africa, and the Middle East [16]. Another study by Powel found that in Zimbabwe there is an organization of Rural Association for Progress (ORAP). The main focus of this association is in the areas of house improvement, sewing of cloths, basketing, poultry keeping, baking, building and construction of building materials. All these activities are geared towards alleviating poverty in those environments.

Similar studies conducted by many researchers revealed that women are motivated into going into entrepreneurship activities as a result of many factors which include: personal characteristics, Lifepath circumstances, and environmental factors.

Hisrich and Brush from their own studies found that the factors are classified into push and pull factors. The push factors according to them include frustration, job dissatisfaction, deployment, divorce and boredom in their previous jobs while the pull factors include independence, autonomy, education and family security [17].

Women face some problems in their entrepreneurship activities. Their problems range from discrimination from the men folk, lack of vital resources for starting and developing their own business, due to the fact that some of them lack the required educational and professional competencies. Some women also do not receive the required support in the areas of finance and moral support from government and family members. For instance, a World Bank Report in 1990 and 2004 stated that women are denied access to capital or affordable financial resources. Though this trend is no longer the same as many government financial assistance favor women more, but many of the women are not aware of their existence. Even when they are aware could not access them due to some other obstacles.

Poverty has also been identified as another major obstacle to women entrepreneurship. A number of factors have been identified as contributing towards the poverty of women in Africa generally and Nigeria in particular. Egwu put it this way: "The gendered division of labor in the household, the low value accorded to women's work with the concomitant in clustering of women in low-paid jobs contributes to female poverty"[13]. She concluded by stating that the plight of the poor is exacerbated by a lack of basic services, poor housing and inadequate infrastructure. In her words "African women have been worst affected by poverty, of all women in the whole world".

\section{Theoretical review}

Theoretically, women participation in entrepreneurship is a desire to make a social contribution and is a strong motivating factor for women entrepreneurs. The desire to help others has been found to be a factor which triggers the spirit of entrepreneurship in women. In addition, Chaganu noted that there is a caring attitude which is natural in women and it manifests in women's leadership traits and styles. 
Women are also motivated to improve their social status in the society by enhancing their positions in the society. Achievement motivation theory (N'Ach) by David McClelland has been perhaps considered the single most important trait which separates entrepreneurs from nonentrepreneurs as reported by Ottih [18].

In view of the above claims and affirmations in the literature, this study is anchored on the Achievement Motivation Theory of David McClelland. The basic assumptions of the achievement theory are: that achievement is more vital than financial reward, achievement motivated people usually favor jobs and responsibilities, feedback are essential since it is imperative for success, achievement motivated people constantly seek improvements and ways of doing things better etc.

In line with the provision of Achievement Theory above, Ottih argues that some people exhibit a greater degree of motivational traits more than others in accomplishing of tasks and in general performance of anything they set to achieve [18]. The theorist referred to this tendency as n'Arch. He maintained that those with high n'Ach are in quest to improve work performance for its own sake. Ottih refers to it as the exhibition of dominant orientation towards personal achievement, freewheeling, openness and energizing republicanism as opposed to skewness towards ascription and loyalties peculiar to the inhibiting authoritarian societies or to one tending towards crippling lethargy and hedonism [18].

Nwachukwu in support of the above, maintained that entrepreneurs share similar characteristics of working at odd hours and closing very late, they made no distinction between office hours and private time, they are compulsive workers who are regularly attached to their job, they like to prove themselves to achieve, and challenge themselves and these are the propositions of the achievement theory of David McClelland of 1961[19].

The theory is highly very relevant to this study because the theorist believe that achievement motivated people are usually those people that achieve results in anything they set to achieve. The assumptions of the theory that are stated above all support the study because what is needed in entrepreneurship is high achievement in order to alleviate poverty in Awka metropolis of Nigeria.

\section{Gap in knowledge}

Entrepreneurship education is very vital in national and economic development of nations all over the world. It is an essential knowledge every student in the higher institution needs to be self-reliant after graduation especially now that the rate of employment seems to be on the increase in developing nations of the world. Scholars and students are eager to discover much about the origin, historical development as well as the roles it is playing in the national and economic development of global economics. Literature in entrepreneurship is rapidly growing and this study is one of the recent developments in the study of entrepreneurship.

Literature reviewed so far on the role of women in entrepreneurship is growing but literature is scanty on the extent of financial assistance of government and moral support of family members on women entrepreneurs towards poverty alleviation in Awka metropolis, hence the present study. This study presents an opportunity to assess the extent at which the Financial Aid recently provided to MSMES by the last Presidential Government with special emphasis on encouraging women participation in entrepreneurship activities actually got to the women. The study will enable government to see how that policy on women entrepreneurship was practically implemented. It will also serve as an avenue to assess the contributions of women in economic and national development in order to disabuse the minds of many people especially the men who see women as the "the never do wells, weaklings, children bearers who are less important in the society and who should not be given any opportunity to excel.

\section{Research Methods}

\section{Research design}

The study employed the descriptive survey design whose purpose according to Ezeani is to collect detailed and factual information that describes an existing phenomenon.

\section{Population of the study}

The target population of the study was all female entrepreneurs in Awka Metropolis both in the manufacturing and service industries. A total population of 450 female entrepreneurs who were registered at the Association of Small and Medium Enterprises in Awka metropolis served the population of the study. The 450 respondents were naturally distributed. 30 are in the manufacturing industries while 420 are in the service industries. This means that a total of 450 organizations participated in the study because the respondents are the entrepreneurs who are the owners of such enterprises. The employees of the organizations are not part of the study.

\section{Sampling procedure and size}

The population of the study was not big hence the whole population participated in the study and this gave a sampling size of 450 respondents. A total of 450 questionnaires were distributed but only 300 was collected which represents $67 \%$ of the population and this is considered adequate for the study.

\section{Source of data for the study}

The data was collected from a primary source since the information required has to do with the practical experiences the female entrepreneurs have in the field.

\section{Empirical measurement of the main variables of the study}

Poverty alleviation was assessed empirically using performance and commitment of the entrepreneurs as the dependent variables. While performance was assessed empirically using output of the employees, efficiency, effectiveness, achievement of goal, numbers of workers employed, customer loyalty and market share, women entrepreneurship was assessed empirically using the existence, awareness, extent and accessibility of government financial and family moral support to women entrepreneurs in Awka metropolis.

\section{Method of data collection}

A structured questionnaire was designed for the study. The questionnaire was made up of two sections. Section 'A' handled the biography of the respondents while section ' $\mathrm{B}$ ' handled the variables of the study. Likert-5 point Scale of strongly agree to strongly disagree.

\section{Validity of the instrument}

The face, content and construct validities of the study were ascertained through expert review. Simple, straightforward questions which were based on the research problem, objectives and research questions were used. 
Citation: Agbionu EO, Agbionu CU, Ikon MA, Chinwe OV (2015) Women Entrepreneurship and Poverty Alleviation in Awka Metropolis. J Entrepren Organiz Manag 4: 158. doi:10.4172/2169-026X.1000158

Page 6 of 9

\section{Reliability of the instrument}

The instrument was subjected to reliability test using test re-test technique. The first test which was represented by $\mathrm{x}$ was correlated with the second test result represented by y. The result shows a correlation coefficient of 0.83 which was considered adequate for the study. The coefficient of correlation $r$ of 0.83 was subjected to a test of significance using Probable Error Method P.E (r) and the result showed a P.E (r) of 0.54 which is less than the correlation coefficient $r$ of 0.83 . According to Gupta (2011) Probable Error of correlation can be used to test for the reliability of correlation. To him, If $r$ is greater than P.E, correlation is significant and hence reliable but if $r$ is less than P.E, then correlation is not significant. In this case, $r$ is greater than P.E and so $r$ is significant and therefore reliable.

\section{Data presentation, Analysis and Results}

The data collected were analyzed using percentages and frequency distributions. The biodata of the respondents shows that 280 respondents which is $93.3 \%$ are in service industries while $20(6.66 \%)$ are in the manufacturing industries. This shows that the female entrepreneurs are more in the service than in the manufacturing industry. The distribution of the ages of the respondents shows that ages below 20 years has 80 respondents which is $26.67 \%$, of the respondents. The age range of $20-30$ has $90(30 \%), 30-40$ has $100(33.33 \%)$ while 50 and above has $30(10 \%)$ of the respondents. This shows that female entrepreneurs fall within the age range of 30-40 more than any other age range. The marital status of the respondents shows that $30(10 \%)$ are married, $90(30 \%)$ are single, $100(33.33 \%)$ are widowed while $80(26.67 \%)$ are divorced. This shows that female entrepreneurs are more in widows, followed by those divorced, single and married women are least entrepreneurs.

The academic level of the respondents show that 175(58.33\%) of the female entrepreneurs did not get any educational qualification above the primary education while $125(41.67 \%)$ possess certificates above the primary education. This shows that female entrepreneurs in Awka metropolis are more among those with only the basic education than those who possess above the basic education. The whole essence of the distribution of the demographic characteristics of the study is both for the understanding of the persistence of the problem of the study and for solutions strategies to be effectively and efficiently implemented.

To accept each item, mean of responses (X) must be greater than mean weights of weights; otherwise, the item is rejected. Any mean that is 2.5 and above is accepted while anyone below 2.5 is rejected. The frequencies of the responses to the questionnaire are presented below in Tables 1 and 2 .

The above table shows that only two statements were accepted while the rest were rejected. The two that were accepted were also against the adequacy of government financial support on the entrepreneurs.

The above table shows that all the statements on the positive influence of government financial support on the performance of the women entrepreneurs were rejected showing that their performance are not positively influenced by the financial assistance from government (Tables 3 and 4).

\begin{tabular}{|c|c|c|c|c|c|c|c|c|c|c|}
\hline $\mathbf{S} / \mathbf{N}$ & Investigative Statements & SA 5 & A & UD 3 & D 2 & SD 1 & Total responses & $\begin{array}{c}\text { Total } \\
\text { points }\end{array}$ & Mean & Decision \\
\hline 1 & I know about Government Financial support. & 30 & 50 & - & 90 & 130 & 300 & 660 & 2.2 & Rejected \\
\hline 2 & I have accessed it & 20 & 30 & - & 120 & 130 & 300 & 590 & 1.966 & Rejected \\
\hline 3 & It is very adequate & 25 & 20 & - & 100 & 155 & 300 & 515 & 1.716 & Rejected \\
\hline 4 & Getting it is too difficult. & 130 & 100 & 50 & 10 & 10 & 300 & 1230 & 4.1 & Accepted \\
\hline 5 & Those who got it didn't find it very useful & 120 & 110 & 40 & 20 & 10 & 300 & 1210 & 4.033 & Accepted \\
\hline
\end{tabular}

Source: Field Survey, 2015

Table 1: Distribution of Responses on the Extent of Government Financial Support on Women Entrepreneurs for Research Question 1.

\begin{tabular}{|l|l|c|c|c|c|c|c|c|c|c|c|c|}
\hline S/N & Investigative Statements & SA 5 & A 4 & UD 3 & D 2 & SD 1 & Total responses & $\begin{array}{c}\text { Total } \\
\text { points }\end{array}$ & Mean & Decision \\
\hline 2 & I rely on Government financial support to be efficient. & 15 & 20 & - & 120 & 145 & 300 & 540 & 1.8 & Rejected \\
\hline 3 & $\begin{array}{l}\text { Government financial support makes me to be effective in } \\
\text { my business. }\end{array}$ & 20 & 30 & - & 100 & 150 & 300 \\
\hline 4 & $\begin{array}{l}\text { The Loans from Government helps me to achieve my goal. } \\
\text { Rejected }\end{array}$ & 10 & 20 & - & 120 & 150 & 300 & 520 & 1.733 & Rejected \\
\hline 5 & Government loan helps me to retain my customers. & 30 & 20 & - & 100 & 150 & 300 & 580 & 1.933 & Rejected \\
\hline
\end{tabular}

Source: Field Survey, 2015

Table 2: Distribution of the Responses on the level of Performance of the Women Entrepreneurs based on Government Financial Support for Research Question I.

\begin{tabular}{|c|c|c|c|c|c|c|c|c|c|c|}
\hline $\mathbf{S} / \mathbf{N}$ & Investigative Statements & SA 5 & A & UD 3 & D 2 & SD 1 & Total responses & $\begin{array}{l}\text { Total } \\
\text { points }\end{array}$ & Mean & Decision \\
\hline 1 & My husband wants me to work on my own. & 15 & 20 & - & 115 & 150 & 300 & 535 & 1.783 & Rejected \\
\hline 2 & My children support my business activities. & 20 & 30 & - & 100 & 150 & 300 & 570 & 1.9 & Rejected \\
\hline 3 & $\begin{array}{l}\text { My parents give me some encouragement to } \\
\text { start my business. }\end{array}$ & 30 & 50 & - & 90 & 130 & 300 & 660 & 2.2 & Rejected \\
\hline 4 & $\begin{array}{l}\text { Generally family members support women being } \\
\text { on their own. }\end{array}$ & 10 & 20 & - & 120 & 150 & 300 & 520 & 1.733 & Rejected \\
\hline 5 & They now believe that women are reliable & 20 & 30 & - & 100 & 150 & 300 & 570 & 1.9 & Rejected \\
\hline
\end{tabular}

Source: Field Survey, 2015

Table 3: Frequency Distribution of the Responses on Family support for Research Question 2. 
Citation: Agbionu EO, Agbionu CU, Ikon MA, Chinwe OV (2015) Women Entrepreneurship and Poverty Alleviation in Awka Metropolis. J Entrepren Organiz Manag 4: 158. doi:10.4172/2169-026X.1000158

Page 7 of 9

\begin{tabular}{|c|c|c|c|c|c|c|c|c|c|c|}
\hline $\mathbf{S} / \mathbf{N}$ & Investigative Statements & SA 5 & A & UD 3 & D 2 & SD 1 & Total responses & $\begin{array}{l}\text { Total } \\
\text { points }\end{array}$ & Mean & Decision \\
\hline 1 & $\begin{array}{l}\text { My husband's moral support makes me to work } \\
\text { hard. }\end{array}$ & 20 & 30 & - & 100 & 150 & 300 & 570 & 1.9 & Rejected \\
\hline 2 & $\begin{array}{l}\text { My children's support helps me to work late } \\
\text { hours. }\end{array}$ & 30 & 15 & - & 100 & 155 & 300 & 565 & 1.883 & Rejected \\
\hline 3 & $\begin{array}{l}\text { My family moral support helps me break down } \\
\text { easily. }\end{array}$ & 10 & 15 & - & 130 & 145 & 300 & 515 & 1.716 & Rejected \\
\hline 4 & $\begin{array}{l}\text { The encouragement from my parents helps me } \\
\text { to be focused. }\end{array}$ & 20 & 30 & - & 100 & 150 & 300 & 570 & 1.9 & Rejected \\
\hline 5 & $\begin{array}{l}\text { Generally my family assists me to be } \\
\text { determined. }\end{array}$ & 30 & 35 & - & 100 & 135 & 300 & 625 & 2.083 & Rejected \\
\hline
\end{tabular}

Source: Field Survey, 2015

Table 4: Distribution of the responses on the positive influence of family moral support to the women entrepreneurs for research question 2.

\begin{tabular}{|c|c|c|c|c|}
\multicolumn{2}{|c|}{ Adequacy of Govt Financial Support (X) } & \multicolumn{2}{c|}{$\begin{array}{c}\text { Performance of Female } \\
\text { Entrepreneur (Y) }\end{array}$} \\
\hline S/N & X & $\%$ & Y & $\%$ \\
\hline 1 & 25 & 8.33 & 20 & 6.67 \\
\hline 2 & 20 & 6.67 & 30 & 10 \\
\hline 3 & - & - & - & - \\
\hline 4 & 100 & 33.33 & 100 & 33.3 \\
\hline 5 & 155 & 51.67 & 150 & 50 \\
\hline
\end{tabular}

Table 5: Presentation of Data for the Testing of Hypothesis.

All the statements on adequacy of family moral support were rejected showing that the support these female entrepreneurs get from their family members are inadequate.

From the above table, all the statements are rejected showing that the moral support from the families do not positively influence the level of commitment of the female entrepreneurs.

\section{Test of hypotheses}

For the test of the two hypotheses, the manual computation of the coefficient of correlation $r$, coefficient of determination and probable error of correlation were applied using their formulas and manual determination of the values of the results.

\section{Test of hypothesis one}

Hypothesis one which stated that Government financial support has not significantly influenced the performance of female entrepreneurs in Awka metropolis was tested as follows: The hypothesis was tested using Pearson's Correlation Coefficient which is represented by the formula below:

$$
\begin{aligned}
& \mathrm{n} \Sigma \mathrm{ny}-\left(\sum \mathrm{x}\right)\left(\sum \mathrm{y}\right) \\
& \mathrm{r}=\left[\mathrm{n} \Sigma \mathrm{x}^{2}-\left(\sum \mathrm{x}\right)^{2}\right]\left(\mathrm{n} \Sigma \mathrm{y}^{2}-\left(\sum \mathrm{y}\right)^{2}\right]
\end{aligned}
$$

Where $r=$ the Pearson Product Movement Correlation Coefficient, $\mathrm{n}$ is the number of observations in the distribution, $\mathrm{x}$ is a value in the distribution of independent variable, $y$ is a value in the dependent variable (Tables 5 and 6).

\section{Coefficient of determination (COD)}

$r^{2}=$ Explained Variation

Total Variation

Where $\mathrm{r}^{2}$ is the proportion of the total variation in the $\mathrm{n}$ observed values of $y$ that is explained by the simple linear regression model.

Since $r=0.985$

\begin{tabular}{|l|l|l|l|l|}
\hline $\mathbf{X}$ & $\mathbf{Y}$ & $\mathbf{X}^{2}$ & $\mathbf{Y}^{2}$ & $\mathbf{X Y}$ \\
\hline 25 & 20 & 625 & 400 & 500 \\
\hline 20 & 30 & 400 & 900 & 600 \\
\hline- & - & - & - & - \\
\hline 100 & 100 & 10,000 & 10,000 & 10,000 \\
\hline 155 & 150 & 24,025 & 22,500 & 23,250 \\
\hline$\sum X=300$ & $\sum \mathrm{Y}=300$ & $\sum \mathrm{X}^{2}=35,050$ & $\sum \mathbf{Y}^{2}=33,800$ & $\sum \mathrm{XY}=34,350$ \\
\hline
\end{tabular}

Source: Field Survey, 2015. $r=0.985$

Table 6: Breakdown of $X$ and $Y$ Variables for Test of Hypothesis 1.

$\mathrm{COD}=\mathrm{r}^{2}=0.9852$

$=0.9852=0.980025 \times 100=98 \%$

The value of $r^{2}$ is $98 \%$ which gives a good fit because it explains that the value of $98 \%$ measures the proportion of the variation in the dependent variable that is explained by the model, while only $2 \%$ is a measure of the proportion of variation in the dependent variable that is not explained by the model. In other words if the independent variable is adjusted positively or negatively, it will influence the dependent variable positively or negatively at the level of $98 \%$ while only $2 \%$ will be influenced by other independent variables not covered by the study. This gave a good fit for decision making purposes.

Testing for the significance of $\mathbf{r}$ using probable error (P.E) method:

$$
\mathrm{P} . \mathrm{E}(\mathrm{r})=\mathrm{S} . \mathrm{E}(\mathrm{r})=\frac{1-r^{2}}{\sqrt{n}}
$$

Probable Error of the Correlation Coefficient is given by

P.E $(r)=0.6740 \times$ S.E $(r)=0.6745$

$\left(\frac{1-r^{2}}{\sqrt{n}}\right)$

0.6745 is used because in a normal distribution, $50 \%$ of the observations lie in the range $6 \pm 0.67450$ where $\mu$ is the mean and 6 in the S.D.

$$
\begin{aligned}
& \text { P.E }=0.6745 \times \text { S. E }(r)=0.6745 \\
& 0.6745 \times\left(\frac{1-0 . .863^{2}}{\sqrt{300}}\right) \\
& =0.6745 \times 1-\frac{0.985^{2}}{\sqrt{300}}
\end{aligned}
$$




$$
\begin{aligned}
& 0.6745 \times \frac{1-0.980025}{17.32} \\
& =0.6745 \times 1-0.0571607 \\
& =0.6745-0.0571607 \\
& =0.6173393 \\
& \text { P. } \mathrm{E}(\mathrm{r})=0.62
\end{aligned}
$$

Since P.E. ( $r$ ) of 0.62 is less than $r$ value of 0,98 , then correlation is highly significant because the decision is that correlation is significant if $r$ is greater than its P.E and not significant if $r$ is less than its P.E. Gupta.

\section{Test of hypothesis two}

Hypothesis two states that family members have not significantly influenced the commitment of female entrepreneurs in Awka Metropolis (Tables 7 and 8).

The hypothesis was also tested using the formulas applied above.

\section{Coefficient of determination (COD)}

$\mathrm{COD}=\mathrm{r}^{2}=$ Explained Variation/Total Variation

If $r=0.863$

$\mathrm{COD}=0.863^{2}=0.744769 \times 100=74 \%$

\section{Significance of $\mathbf{r}$ by probable error (P.E) method}

$$
\begin{aligned}
& \text { S.E }(r)=\frac{1-r^{2}}{\sqrt{n}} \\
& \text { P.E }(r)=0.6745 \times \text { S.E }(r)=0.6745\left(\frac{1-r^{2}}{\sqrt{n}}\right)
\end{aligned}
$$

0.6745 is used because in a normal distribution $50 \%$ of the observations lie in the range $6 \pm 0.67450$ where $\mu$ in the mean and $b$ in the S.D.

$$
\text { P. } \mathrm{E}=0.6745 \mathrm{X} \text { S.E }(\mathrm{r})=0.6745
$$

\begin{tabular}{|l|c|c|c|c|}
\hline \multicolumn{3}{|c|}{$\begin{array}{c}\text { Adequacy of Family Support } \\
\text { Commitment of }\end{array}$} & \multicolumn{2}{c|}{$\begin{array}{c}\text { Commitment of Female } \\
\text { Entrepreneurs }\end{array}$} \\
\hline S/N & X & $\%$ & Y & $\%$ \\
\hline 1 & 20 & 6.67 & 20 & 6.67 \\
\hline 2 & 30 & 10 & 30 & 10 \\
\hline 3 & - & - & - & - \\
\hline 4 & 90 & 30 & 130 & 43.3 \\
\hline 5 & 160 & 53.33 & 120 & 40 \\
\hline
\end{tabular}

Table 7: Presentation of Data for the test of hypothesis two.

\begin{tabular}{|l|l|l|l|l|}
\hline $\mathbf{X}$ & $\mathbf{Y}$ & $\mathbf{X}^{\mathbf{2}}$ & $\mathbf{Y}^{\mathbf{2}}$ & $\mathbf{X Y}$ \\
\hline 20 & 20 & 400 & 400 & 400 \\
\hline 30 & 30 & 900 & 900 & 900 \\
\hline- & - & - & - & - \\
\hline 90 & 130 & 8,100 & 16,900 & 11,700 \\
\hline 160 & 120 & 25,600 & 14,400 & 19,200 \\
\hline$\sum \mathrm{X}=300$ & $\sum \mathrm{Y}=300$ & $\sum \mathrm{X} 2=35,000$ & $\sum \mathrm{Y} 2=32,600$ & $\sum \mathrm{XY}=32,200$ \\
\hline
\end{tabular}

Source: Field Survey, 2015. $r=0.985$

Table 8: Breakdown of $X$ and $Y$ Variables for Test of Hypothesis two.

$$
\begin{aligned}
& =0.6745 \times\left(\frac{1-0.863^{2}}{\sqrt{300}}\right) \\
& =0.6745 \times 1-0.744769 / 17.32 \\
& =0.6745 \times 1-0.0430005 \\
& =0.6745-0.0430005 \\
& =P . E(r)-0.6314995 \\
& =P . E(r)=0.63
\end{aligned}
$$

Since $r=0.74$ is greater than its P.E (r) which is 0.63 , then correlation is significant.

\section{Discussion}

The study examined the influence of government financial support and family moral support on the performance and commitment of the female entrepreneurs in Awka Metropolis in Anambra State, Nigeria. A test of null hypothesis one revealed that the coefficient of correlation ( $r$ ) value of 0.985 . This shows a high positive correlation between government financial support and the performance of female entrepreneurs in Awka metropolis. The interpretation of this result shows that the valuables $\mathrm{x}$ which is the government financial support and $y$ which is the performance of female entrepreneurs move in the same positive direction. This implies that any increase or decrease in $\mathrm{x}$ will lead to the same increase or decrease in $y$ and vice versa.

But because coefficient of correlation $r$ is not strong to determine the causes and effects of such increase or decrease interaction of $x$ and $y$, the coefficient of Determination (COD) was carried out. COD was used to predict the extent of influence any increase or decrease in the independent variables would have on the dependent variables. For the first hypothesis, a COD of $98 \%$ was got which showed that any increase or decrease in government's financial assistance to female entrepreneurs would have a $98 \%$ influence on the performance of female entrepreneurs in Awka Metropolis. This gives a good fit because other variables could only contribute $2 \%$ to the relationship and so it is very negligible.

In the same way, any increase or decrease in the moral support the female entrepreneurs receive from their family members will give a $74 \%$ increase or decrease in the performance of female entrepreneurs. This also gives a good fit because other variables apart from the family moral support produces $26 \%$ influence on the commitment of female entrepreneurs.

The general conclusion here is that the government and family support are very important in the positive contribution of women entrepreneurs towards poverty alleviation in Awka metropolis. Since the results of the survey on the experiences of these women shows that these two supports have been inadequate, there is need therefore for the support to be made adequate. Making the support adequate will involve the government and family to ensure that they provide enabling environment for these women to put in their best to make sure that poverty is alleviated in Awka metropolis.

The test of the significance of the correlation coefficients of the two hypotheses indicated that the two correlations are significant at P.E (r) 0.62 for the first hypothesis and 0.63 for the second hypothesis. This made the two null hypotheses to be rejected and alternatives accepted. The implication of the above result is that if the government and the families have been assisting these female entrepreneurs, they would have been performing well because the two independent variables 
were found to have significant relationships with the two dependent variables.

The results show that financial support is very vital in the performance of entrepreneurs. Egwu stated in support of the above that the entrepreneurs work environment must have availability of infrastructural facilities such as accessible roads for all the suppliers, for instance supplying of raw materials and supplying of finished goods, vehicles for movements, machines and spare parts that relate to job performance and water supply are highly needed [2]. This is because money is needed to procure all the above materials. In addition to the above, Udu et al. states that converting the entrepreneurial idea into reality requires some financial support. According to them such financial support is provided by venture capitalists [20]. Venture capitalists earn their return primarily in the form of capital gain. Again, financial resources needed to form or start a new business must be readily available. Despite the fact that majority of the start-up money needed to start new ventures usually come from the savings of people, credits, friends, and relatives, there is also need for money to come from seed capital or other type of risk capital.

From the above discussion, the study found as follows:

- That many female entrepreneurs in the Awka Metropolis are not aware of the existence of government's financial support to female entrepreneurs.

- Those who are aware do not know how to go about accessing the fund.

- That those who know about it could not succeed due to strict and complicated procedures of accessing the fund.

- That many women confess of strong discouragement from family members especially husbands, parents and others.

- That some help they have ever received comes mainly from friends and acquaintances.

\section{Conclusion}

The study examined the extent of government financial support, and family support female entrepreneurs receive from government and family members. This was necessitated due to the persistent financial and moral problems female entrepreneurs, face in contributing their quota in alleviating poverty in Awka metropolis. The study engaged in a survey of the practical experiences of these women entrepreneurs and results revealed that their claims are practically true.

Based on the findings, the study concluded that government financial support and family moral support to women entrepreneurs have not been adequate but will be made more adequate if government supports them and goes further to increase their awareness of the existence of the support and also make the financial support more accessible by removing a lot of complicated procedures attached to the loans. Family members also have been obstacles in the ways women are committed in their entrepreneurial activities for poverty alleviation in Awka metropolis.

\section{Recommendations}

Based on the above conclusions, the study recommends as follows:

- That the government should devote more financial support to female entrepreneurs in Awka metropolis.

- That the financial support should be made aware to them through organizing seminars for these women

- That the mode of accessing the loans should be highly simplified so that the women can access them

- That there should general awareness campaign on the positive contribution of women especially the enterprising ones for the general public so that they can be better informed on the essence of women involvement in entrepreneurship.

\section{Refernces}

1. Agbionu CU (2014) Research and Statistics in Management (Theory and Practice). SCOA Publishers, Awka.

2. Egwu U (2011) Development of Entrepreneurship. EBSU Press, Abakaliki.

3. Sexton DC, Kent C (1981) Female Executives and Entrepreneurs: A Preliminary Comparison. Babson University Press, Wellesley.

4. Carter S, Cannon T (1992) Women as Entrepreneurs. Academic Press Limited London.

5. Chinonye LE (2010) Entrepreneurship: A Conceptual Approach. Rumark Nigeria Limited, Lagos.

6. Mayoux L (2001) Gender and Small Enterprises. Getting the policy environment right.

7. Ndubuisi F (2004) Bankers Lost Financial Alternative for SMCs, in CBN Seminar or Small and Medium Industries Equity Investments Scheme.

8. Kirks V, Bolvics R (2006) Counseling would-be Entrepreneurs. Journal of Employment Counseling 43: 50-62.

9. UNIDO (2001) Women Entrepreneurship Development in Selected African Countries.

10. Bardasi E (2007) Gender Entrepreneurship and Competitiveness in Africa" The African Competitiveness Report.

11. International Finance Corporation (2007) Voices of Women Entrepreneur in Tanzania. World Bank Group, Washington.

12. Agbionu CU, Ibenta SN, Egbunike PA (2013) Entrepreneurship and Nigeria Economic Development for Poverty Alleviation: The Missing Link. Sacha Journal of Policy and Strategic Studies 3: 63-72.

13. Egwu J (2011) Women Entrepreneurship. EBSU Press, Abakaliki.

14. Ubong B (2007) Developing Women Entrepreneurs for National Development

15. Agbionu CU, Agbionu EO (2013) Poverty Alleviation in Nigeria.

16. OECD (1998) Women Entrepreneurship in Small and Medium Enterprises, Paris.

17. Hisrich RD, Brush CG (1985) The Women Entrepreneur: Characteristics and Prescription for Success. Lexington Books, Lexington.

18. Ottih LO (2000) Entrepreneuring, Pearl Publishers, Port Harcourt.

19. Nwachukwu CC (1990) The Practice of Entrepreneurship in Nigeria. Africana Press Publishers Ltd, Onitsha.

20. Udu AA (2008) Entrepreneurship. Rhyce Kerex Publishers, Enugu. 